\title{
An assessment of the effects of unconventional monetary policies on the cost of credit to non-financial companies in the eurozone
}

\author{
Désiré Kanga * and Grégory Levieuge *
}

\begin{abstract}
The aim of this paper is to assess the effects of unconventional monetary policies (UMPs) on the cost of credit to non-financial companies in the eurozone. We analyse the direct effects of these UMPs using a multiple linear regression, then we seek to highlight the existence of a complementarity between these policies and the interest rate policy - an indirect effect of UMPs - using an interaction term. We show that the direct effects of UMPs are limited, indeed nil depending on the country, and are always weaker than their indirect effects. After having highlighted the heterogeneity of the indirect effects of UMPs in the eurozone, we offer diverse interpretations - macroeconomic, financial or banking differences, depending on the country - using a Panel Conditionally Homogenous VAR model (PCHVAR). The indirect effects of UMPs, depending on the economies considered, were countered by large public debt, a banking sector in poor health and/or a high level of systemic risk or risk of default.
\end{abstract}

JEL Classification: E52, G20

Keywords: unconventional monetary policies, credit cost, heterogeneity, direct and indirect effects

Reminder:

The opinions and analyses in this article are those of the author(s) and do not necessarily reflect their

institution's or Insee's views.
*Laboratoire d'économie d'Orléans (UMR CNRS 7322) (kouame-desire.kanga@etu.univ-orleans.fr and gregory.levieuge@univ-orleans.fr).

Aknowledgments: we would like to express our gratitude to the participants of the seminar of November 10 $0^{\text {th }}, 2016$, held at the University of Poitiers and to the two anonymous reporters for their comments and suggestions. We would also like to thank Yannick Lucotte for having made available to us a certain amount of data, and for his useful suggestions. 
$\mathbf{T}$ he financial and banking crisis which began in 2007 led in part to an increase in risk and liquidity premiums, and to a decline of financing going to households and companies. In response, central banks aggressively lowered their key interest rate, including the European Central Bank (ECB), albeit in lesser proportions than the American Federal Reserve (Fed).

The reduction of key interest rates was meant to increase the price of assets and reduce the cost of capital, and to recover investment and growth. However, it appeared that this interest rates policy was insufficient, in particular to avoid the differences in the real cost of credit to non-financial corporations (NFCs) in eurozone countries getting wider (cf. online complement $\mathrm{C} 1$, figure $\mathrm{C} 1-\mathrm{I})$. Whereas the average cost of new borrowings was lower than $3 \%$ in certain countries (Austria, Germany, Belgium, France, Finland and the Netherlands), it exceeded $6.5 \%$ in Greece and Portugal between the start of the 2010s and 2014. The reduction of key interest rates was not enough to regain confidence, especially as the sovereign debt crisis came to add to the financial and banking crisis. The spread between Greece's and Germany's 10 year rate was higher than 10 percentage points (pp) between April 2011 and April 2013 and Portugal's oscillated between 5.85pp and $12 \mathrm{pp}$ over the course of this period. The rise in risk premiums on government bonds has weakened banks, whose assets were mainly made up of these bonds, thus making it very difficult for them to refinance themselves and also to lend to economic actors. Specifically, this rise of risk premiums brought on an increase in the cost of external financing for banks, which they have passed on to lending rates and/or by rationing credit $^{1}$ (Avouyi-Dovi et al., 2017).

In this situation, in order to improve the economy's financing conditions, central banks adopted, in 2008, so-called unconventional monetary policies (UMPs), that being other than those acting mainly through the choice of key policy rates. Put in place from the start of the subprime crisis in the form of a direct injection of liquidity to banks in order to alleviate the paralysis of the interbank market, they were widened in October 2008. UMPs (unconventional monetary policies) consist of a use of the balance sheet (supply of liquidities at a fixed and/or long-term rate and targeted purchases of securities) intended to affect the prices of assets and financing conditions, in addition to the lowering of key policy rates ${ }^{2}$ and the introduction of forward guidance (central bank communication). We will outline, a bit later on, the measures implemented by the ECB. But, before that, it should be noted that UMPs do not include Emergency Liquidity Assistance (ELA) that national central banks generally grant to solvent banks which are no longer capable of refinancing themselves. The ELA was extended during the crisis to the banking system in Greece and Ireland especially in order to ensure their survival, two countries which were receiving financial assistance from the EU and the IMF during the eurozone crisis. ${ }^{3}$

Like the ECB, the Fed also implemented unconventional measures over the course of the crisis. Nevertheless, the implementation of these measures is slightly different in the eurozone compared to the US, notably due to differences in the structures of their economies. Furthermore, the functioning of the American interbank market has been gradually normalised from 2009 onwards while it has remained very disrupted in the eurozone due to the sovereign debt crisis, thus requiring a series of unconventional measures in the eurozone.

The UMP measures are supposed to have direct effects on the economy via four transmission channels reproduced in diagram $\mathrm{C} 1$ (see online complement C1). Firstly, the massive purchase of public and private bonds and the widening of assets accepted as collateral over the course of open market operations should unblock transactions on target markets and thus lead to a drop in risk premiums. Risk premiums had in fact dramatically increased at the height of the crisis, when investors were reluctant to acquire assets that they then risked not being able to resell (liquidity effect). Also, a reallocation of investors' portfolios is expected from the unconventional measures. In fact, the massive purchase of risk-free assets raises their price and lowers their return, which, on the one hand, reduces the level of interest rates required for new issuances of securities, and on the other hand, encourages investors to turn to other more available and lucrative (private) assets, whose demand will also reduce the required return. The purchases of assets together with supplies of liquidity should encourage banks to grant loans to non-financial companies (NFCs).

\footnotetext{
1. The question of pass-through between sovereign credit risk and bank credit was the subject of considerable treatment over the course of these last few years. See for example Bottero et al. (2015) and Popov \& Van Horen (2013) for empirical evidence and Bocola (2016) for a theoretical demonstration.

2. With base rates already near zero, the room for manoeuvre had become nil (cf. figure C1-Il of the online complement). 3. See Praet (2016)
} 
In fact, other than the purchase of assets, the supplies of liquidity sought to support banks' short-term financing in order to attenuate the potential negative impact of liquidity risk on the availability of credit to households and NFCs in the eurozone. Also, interest rate risk is reduced when the central bank commits to keeping key policy rates low over a long period (duration effect). Finally, these unconventional measures should restore confidence. In particular, the ECB's unlimited fixed-rate allotment coupled with the extension of the maturity of long-term operations ease banks' refinancing conditions and should allow financial institutions to hold liquidity at a low rate over a longer period. Moreover, by buying assets, including those of average quality, central banks are reassuring investors and inciting them to do the same (signalling effect). Duration and signalling effects must reduce risk premiums. Then, by lowering the costs of financing, these measures should stimulate aggregate demand, helped by a depreciation of the exchange rate, until the rate of inflation gets back to its usual level of $2 \%$ per year. Then, it would return to a conventional monetary policy regime.

Unconventional policies do not just target direct effects on the economy's financing conditions. They are also meant to support the reduction of the key policy rates - to a level close to zero-so that they regain their influenceover credit conditions, as is the case in normal times (Cour-Thimann and Winkler, 2012; Trichet, 2010). From this angle we speak of the "indirect" effects of unconventional policies, whose objective is also to restore the transmission mechanism of monetary policy.

The ECB has implemented several measures, from fixed-rate full allotment procedure in 2008 to targeted long-term financing operations (TLTRO II) announced in 2016, through massive purchases programmes of public and private bonds carried out each year since the beginnning of the crisis. Indeed, with regards to the different transmission channels mentioned above, the objectives of unconventional monetary policies have been multiple: restoring the effectiveness of rates policy, meeting liquidity needs, lowering sovereign premiums, etc. However, as pressures on allthe markets led to an increase in the cost of for NFCs (cf. figure $\mathrm{C} 1-\mathrm{I}$ of online complement $\mathrm{C} 1$ ), the UMPs should have an impact on the borrowing cost of the NCFs and households. This is an intended objective of the ECB, which through its president has called its interventions as "enhanced credit support"4 (Trichet, 2009, 2010). Specifically, unconventional measures such as those taken by the ECB should alleviate banks' financing constraints (lowering rates on monetary and interbank markets, providing unlimited fixed-rate liquidity). Then, any lowering of the cost of financing for banks should lead to a lowering of the cost of credit for businesses.

The aim of this article is to evaluate the effects of unconventional monetary policies on the cost of credit to companies in eurozone countries. It can be very hard to analyse the effects of unconventional measures on credit volumes. Typically, Creel et al. (2016) find that the unconventional measures greatly lowered lending rates but that the transmission towards credit volume was weak. Carpenter et al. (2014) found similar results. The historically low level of interest rates has had a negative effect on loan supply. The weak demand of financing may also explain the slow transmission from rates to quantities. Generally, the studies on quantities encounter the usual difficulty of distinguishing between supply and demand effects. For all these reasons, our assessment of the effects of UMPs will focus on the cost of borrowing for NFCs.

The empirical literature attests to the overall effectiveness of unconventional measures in terms of reduction of interest rates on the credit market (Abbassi \& Linzert, 2012; Aït-Sahalia et al., 2012; Darracq-Paries \& De Santis, 2015; Hesse \& Frank, 2009, among others). However, these works often overlook the indirect effects (Creel et al., 2016). Moreover, by providing an average effect, they overlook the heterogeneity of the effects on the eurozone Member States. However, recent studies (e.g., Avouyi-Dovi et al, 2017; Horny et al, 2016) show that the sovereign debt crisis has accentuated the heterogeneity of the transmission of monetary policy in the eurozone. Attempts to estimate the effects of policies by country have recently been initiated without covering a large panel of countries, nor all the programs implemented (Beaupain \& Durré, 2016; Gibson et al., 2016; Szczerbowicz, 2015). Finally, they do not explain the potential sources of divergences of the impact across countries. However, we know for example that structural heterogeneity (Leroy \& Lucotte, 2016; Mojon, 2001) and cyclical

\footnotetext{
4. "Enhanced credit support constitutes the special and primarily bank-based measures that are being taken to enhance the flow of credit above and beyond what could be achieved through policy interest rate reductions alone" (Trichet, 2009).
} 
factors (Sorensen \& Werner, 2006) are sources of divergence in the adjustment of bank rates to changes in policy rates.

Our analysis contributes to be the literature in several respects. First of all, it analyses all the unconventional measures implemented by the ECB (with the exception of forward guidance), until the end of 2014, and covers a panel of 11 countries that is large enough to give an overall view of the existing disparities. ${ }^{5}$ Second, we then seek to highlight the existence of a complementarity - called indirect effect between unconventional policies and interest rate policy. Third, we analyse the indirect effects of unconventional measures, of which the objective is to restore the link between base rates and the cost of credit. Fourth, we attempt to explain the heterogeneity in the transmission of the effects of unconventional policies by using a panel conditionally homogeneous VAR model (PHCVAR).

We find that the direct effects of unconventional policies are much less compelling than the indirect effects. However, these indirect effects are heterogeneous. The asymmetry of the responses is explained, on the one hand, by macro-financial differences between the countries, relative to their growth rate, the probability of default for companies, public debt and systemic risk. It is due, on the other hand, to the heterogeneity of banking sectors, through differences in capitalisation and in non-performing loans. Competition and the concentration of the banking sector would have had a weaker effect on the differences of the transmission of interest rate policy. From this point of view, the effects of unconventional policies would have been greater in Germany and Austria, for example, than in Greece, Italy, Spain or Portugal. Such results lead to a balanced assessment of unconventional policies in Europe. In fact, they reduced the overall cost of financing of companies and banks. They also contained bank and sovereign default risks. But, strictly from the point of view of the cost of credit, they may not have been the most effective where the needs were comparatively greater.

This article is organised as follows. The next section presents a review of the ECB's unconventional measures and of their effects on financing conditions. Then we analyse the direct effects of unconventional policies and their indirect effects, and seek to explain the heterogeneity of the impact of unconventional measures.

\section{A review of the ECB's unconventional measures and of their effects on financing conditions}

Typically, exceptional policies led by monetary authorities over the course of the crisis are labelled as unconventional because (i) they do not treat solely the management of short-term interest rates, (ii) the amounts of liquidity injected are considerable, (iii) they substantially modify the structure and size of central banks' balance sheets, et (iv) their transmission channels differ a priori from those of interest rates policy.

Usually, UMPs are classified in two categories: quantitative policies and qualitative policies $^{6}$ (Bernanke et al., 2004). A quantitative policy leads to an increase in the size of the balance sheet of the central bank, which is linked to the supply of liquidity to the economy. Qualitative policies consist of modifying the composition of the central bank's balance sheet, without modifying the size. In practice, from the time of the subprime crisis, central banks (Fed, Bank of England, Bank of Japan and ECB) have led both quantitative and qualitative policies, which have increased the size of the balance sheets.

In this section, we present, as an overview, the measures implemented by the ECB between 2008 and 2016 as well as a review of the empirical literature on the evaluations of the effects of these measures.

\section{The unconventional policies put in place by the $E C B$}

The ECB's initiatives, whose chronology is given in table C1-1 of online complement $\mathrm{C}$, include five large-scale operations that can be labelled as unconventional. The ECB led both quantitative and qualitative measures. ${ }^{7}$ The distinction between quantitative and qualitative

\footnotetext{
5. The 11 countries considered are Belgium, Germany, Ireland, Spain, France, Italy, the Netherlands, Austria, Portugal, Finland, and Greece. They contribute to $98 \%$ of the eurozone's annual GDP.

6 . In a more general way, unconventional policies draw on a very vast set of measures and propositions. These policies encompass taxation on the holding of monetary assets, (Goodfriend, 2000; Goodhart \& Ashworth, 2012: McCallum, 2000), the depreciation of currency (McCallum, 2000) or the targeting of a general price level (for example Eggertsson, 2003, 2006; Eggertsson \& Woodford, 2003; Jeanne and Svensson, 2007; Krugman, 1998; Svensson, 2001, 2003). We will focus on the policies implemented from 2008 onwards.

7. For Borio and Disyatat (2010), these interventions are credit policies, a priori qualitative, since the emphasis was put on bank credit and the $E C B$ has accepted risk assets that it would not before accept as guarantees. However, these interventions were followed by a growth of the ECB's balance sheet.
} 
measures are not clear and absolute. Therefore, we do not separate them in this article. ${ }^{8}$

Swap agreement: To support the banks which were faced with a constraint on foreign currencies following the fall of Lehman Brothers in September 2008, the ECB implemented measures to ensure the provision of liquidity in foreign currencies from April 2009 onwards. ${ }^{9}$ It also supported the provision of liquidity in euros in the banking systems of several non-Member States of the eurozone, with agreement from the Central Banks of these States.

Fixed-rate full allotment (FRFA): It is a main refinancing operation (MRO) of the ECB, of weekly frequency, in which the amount of liquidity requested by the tenderers is fully allocated at the rate fixed by the Central Bank. In other words, banks can finance themselves to an unlimited extent with the Central Bank. This way of proceeding differs from the classic MROs which incorporate a pro-rata adjudication. The main aim of these measures is to support the short-term financing of banks in order to attenuate the negative impact of the illiquidity risk on the distribution of credit to households and businesses. This procedure was announced for the first time on 8 October 2008 just after the fall of Lehman Brothers. It has been regularly renewed since then.

Collateral easing: Another way of increasing the quantities of liquidity consists of facilitating banks' access to refinancing operations, through the collateral easing during MROs (Cheun et al., 2009). The collateral easing was put in place in October 2008, so as to evolve thereafter. These assets concerned the bank bonds negotiated on unregulated markets, instruments of subordinated debts protected by an acceptable guarantee, securities graded below BBB- (except for asset-backed securities, ABS), and guarantees denominated in foreign currencies (Yen, Pound Sterling, US Dollar) which fulfil all the other usual admission criteria.

Negative rate: In order to encourage banks to use their reserves to conduct activities of intermediation, the ECB has introduced from June 2014 onwards a negative rate on its deposit facilities.

Extension of the maturity of refinancing operations (LTROs and TLTROs): The ECB has extended the maximum maturity (to 48 months) of its operations by allowing banks to hold liquidity over a long period. From 4 September 2008, the ECB decided to conduct three longer-term refinancing operations, of a total value of 125 billion euros. Two of these operations of a value of 50 billion euros each had a three year maturity and the other 25 billion euros had a six month maturity. Moreover, this operation coupled with the procedure of fixed-rate full allotment should maintain the interest rate on the monetary market at a low level and ease refinancing conditions for banks. Other than the extension of the maturity of LTROs (Long Term Financing Operations) and the decision to apply a negative rate to the deposit facility, the ECB decided on 5 June 2014 to conduct two waves of targeted LTROs (TLTROs). The first wave of TLTROs, implemented between September and December 2014, should have allowed banks to borrow from the ECB the equivalent of $7 \%$ of their total outstanding amount of loans at 30 April 2014, at the rate of the MROs increased by 10 basis points (that is $0.25 \%$ ). In the second phase, implemented between March and June 2016, banks were able to borrow extra amounts during the quarterly TLTROs, provided that they iincreased their loan to firms and households. The TLTROs have a maturity of 48 months, with the possibility of reimbursement after two years. By indexing its credit to banks' outstanding amount on loans, the ECB wished to relaunch credit activity.

Asset purchase programmes: The ECB implemented four categories of security purchase programmes. The first dealt with covered bonds. Two covered bonds purchasing operations were conducted. The first (CBPP1), announced 7 May 2009, was implemented between July 2009 and June 2010. The cumulated outstanding amount of the purchases at 30 June 2010 was 60 billion euros. A second purchase programme (CBPP2) was announced on 6 October 2011, to be implemented between November 2011 and October 2012. The targeted total amount of covered bonds to be purchased under this phase was 40 billion euros. It aimed to soften banks and NFCs financing conditions. At the end of the programme (31 October 2012), the cumulated outstanding amount of purchased bonds was estimated at 16.4 billion euros. The last programme (CBPP3) was decided on 4 September 2014 , for an initial duration of 2 years.

8. We tried to carry out, in table C1-2 (see online complement C1), a classification of the unconventional measures in order to emphasize on those that aim to affect the borrowing cost of NFCs. Nevertheless, even if the measures do not affect directly the borrowing cost of NFCs, they are not likely to indirectly affect this cost by way of their direct effect on banks' financing.

9. The swap agreements have always existed between the ECB and other central banks. We limit ourselves to operations conducted over the course of the financial crisis of 2007. 
The second category (called SMP for Securities Market Programme) phased-in between May 2010 and May 2012 focused on Government and private sector bonds. It was introduced following the sovereign debt crisis and aimed to guarantee the liquidity and depth in dysfunctional bond market segments (Greece, Ireland, Portugal, Spain and Italy). The oustanding amount of the purchases reached to 208.8 billion euros at 14 September 2012.

Outright Money Transactions (OMTs) constitute the third category of purchase programmes. They aimed to buy, under certain conditions, ${ }^{10}$ bonds issued by Member States of the eurozone. This programme was announced on 2 August 2012, shortly after Mr Draghi's speech of July 2012 (see further on), to begin in September 2012 and thus put an end to the SMP.

The fourth asset purchase programme was decided on 4 September 2014. It began in November 2014 and consists of buying asset-backed securities (ABSPP for Asset-Backed Securities Purchase Programme). Scheduled to run for two years, it was a joint programme with CBPP3. On 22 January 2015, the ECB decided to conduct an extended asset purchase programme (APP) which encompasses the two ongoing programmes (ABSPP \& CBPP3) and a sovereign bond purchase programme (PSPP for Public Sector Purchase Programme). The measures were to be among the most significant since the start of the crisis, as regard to the targeted amount (monthly target of 80 billion euros between April 2016 and March 2017 whereas the monthly target was 60 billion euros between March 2015 and March 2016) and of their duration. ${ }^{11}$ At 31 May 2016, the outstanding amount of the purchases is estimated at just over 1,000 billion euros. The programme whose end was initially on the end of March 2017, conditional to inflation returning to around $2 \%$, is being extended until the end of December 2017 or even later, if needs be. The purchases concern in particular bonds issued by European central administrations, agencies and institutions in the eurozone.

As figure C1-III (online complement C1) shows, unconventional policies have modified the size and structure of the ECB's balance sheet. Its size nearly tripled between 2005 and 2013. Two evolutions are particularly pronounced. One took place at the end of 2008 in the aftermath of Lehman Brothers' collapse. The other, even more dramatic, appeared in 2011 with the implementation of the second covered bond purchase programme (CBPP2) and the SMP.
Moreover, the composition of the balance sheet follows longer-term refinancing operations between 2009 and 2010 and at the end of 2012. Another important modification concerns the deposit facilities since the start of the rolling out of these easing policies. Banks made great use of the central bank's deposit facility which led to the build-up of reserves, rather than using resources to grow their supply of credit to companies and households. The ECB, then, decided to bring the interest rate on deposits back down to $0 \%$ in July 2012 then $-0.1 \%$ in June 2014 . It has been fixed at $-0.40 \%$ since March 2016 . In other words, the central bank taxes banks' deposits in order to encourage them to mobilise their resources to either lend them to firms or invest them in income-generating securities.

In terms of composition, assets other than securities and States' debts have seen considerable evolution since the start of the crisis, which attests to the extension of the range of assets that the ECB has accepted as collateral. Liabilities with regards to financial institutions in the eurozone have also considerably increased, attesting to the role played by the ECB as an actor of the interbank market.

Finally, since the beginning of the crisis, central banks have announced in a more systematic and pronounced way their intentions on key interest rates via forward guidance. In uncertain circumstances, governors' speeches aim to guide the anticipations and behaviour of investors. So, since July 2013, the ECB, through its president Mr Draghi, has announced its intentions for the future of the main policy rate (without however providing a very clear schedule or set of conditions). A year before (July 2012), President Draghi announced the Eurosystem's intention to take all the necessary measures, "whatever it takes", to save the euro.

\section{$A$ literature review of the impact of ECB'S UMPs on financing conditions}

There is, today, an extensive literature on the measure of the effects of unconventional policies on the economy's financing conditions. Due to the lack of historical series, the first

10. The participating countries must be engaged in an adjustment programme via the European Financial Stability Facility or the European Stability Mechanism. Even if no quantitative limit was fixed regarding the size of the program, the purchases focus, in particular, on sovereign bonds with a maturity of one to three years.

11. https://www.ecb. europa eu/mopo/implement/omt/html/index en $h$ tml (visited on 11/06/2016). From March 2015 to March 2016, the targeted monthly sum was 60 billion euros. 
works focused on events studies. Aït-Sahalia et al. (2012) conclude, drawing on this technique, with a decline of the risk and liquidity premiums on the interbank market following the announcement 1) of the lowering of base interest rates, 2) of liquidity injection and 3) of foreign currency swaps. By definition, this technique only allows for the evaluation of the effects of the announcements, and the size of the window plays a crucial role to the extent that, when it increases, it becomes difficult to attribute the measured effects to the targeted policies. Other methods have been used to overcome this shortcoming. Certain authors have used term structure models (e.g., De Pooter et al., 2015; Fourel \& Idier, 2011) to assess the effect of unconventional policies on the price of assets and on the risk and liquidity premiums. Others have estimated models with one equation (Abbassi \& Linzert, 2012; Eser \& Schwaab, 2016; Gambacorta \& Marques-Ibanez, 2011; Gibson et al., 2016; Szczerbowicz, 2015), or used VAR models (Abbassi \& Linzert, 2012; Beaupain \& Durré, 2016; Creel et al., 2016; Darracq-Paries \& De Santis, 2015; Fourel \& Idier, 2011; Gambacorta et al., 2014; Giannone et al., 2012; Hesse \& Frank, 2009; Lenza et al., 2010; Peersman, 2011). Overall, these studies conclude with an effectiveness of UMPs in terms of reduction of interest rates on the credit market thanks to their effects on risk and liquidity premiums. The UMPs would have limited the collapse of bank lending (Gambacorta \& Marques-Ibanez, 2011).

However, most of these works give an average measurement of the effects of these policies, without taking into account the heterogeneity in the eurozone. Even if some models are estimated over a panel of countries, controlling for fixed effects does not take into account the specific responses of a given country to monetary poly impulses. It is to alleviate this shortcoming that some recent studies have tried to estimate the effects of policies on certain countries within the eurozone (Beaupain \& Durré, 2016; Fourel \& Idier, 2011; Gibson et al., 2016; Szczerbowicz, 2015) or have used models with heterogeneous coefficients estimated over a panel of countries (Eser \& Schwaab, 2016). Nevertheless, these works focus on a reduced number of programmes and countries. For example, Eser and Schwaab (2016), Fourel and Idier (2011) and Gibson et al. (2016) focus exclusively on asset purchase programmes (SMP and CBPP) whereas Beaupain et Durré (2016) analyse the effects of the FRFA procedure. Szczerbowicz (2015) analyses a wider panel of unconventional measures but is limited to six countries (Spain, France, Greece, Ireland, Italy, Portugal).

We contribute to this literature in four ways. Firstly, our analysis covers a panel of 11 countries in the eurozone which are Germany, Austria, Belgium, Spain, Finland, France, Greece, Ireland, Italy, the Netherlands and Portugal. To our knowledge, only Carpenter et al. (2014) and Darracq-Paries and De Santis (2015) have studied as many countries. But their analyses remain aggregated.

Secondly, we cover almost all of the unconventional policies measures initiated by the ECB before 2014. Moreover, we evaluate the effects of each of these policies on the cost of borrowing in each country, highligting the heterogeneity of the transmission of these policies' effects.

Thirdly, we highlight the complementarity between unconventional policies and interest rate policy. With the exception of Antonin et al. (2014) and Creel et al. (2016), nearly all the studies analyse either conventional monetary policy, or unconventional monetary policies. But, as we outlined in the introduction, unconventional policies also (and maybe especially) aim to restore the functioning of the traditional channels of monetary policy. It is therefore necessary to evaluate the effects of UMPs by taking into account this dimension.

The study of heterogeneity in the transmission of the effects of unconventional policies makes up our fourth contribution. Generally, a vast literature exists showing that the heterogeneity in the eurozone might be at the origin of the asymmetry in the transmission of the effects of rates policy (e.g. Angeloni et al., 2003). Likewise, the structural heterogeneity of the eurozone could explain the asymmetrical effects of unconventional measures, all the more so since this heterogeneity has led to financial fragmentation (strong heterogeneity in the financing conditions of banks and companies). This is why, after analysing the direct and indirect effects of UMPs, we will use a conditional model in order to determine that factors likely to explain the heterogeneity of the effects between the countries.

\section{Direct effects of unconventional policies on the cost of credit}

In this section, we analyse the direct effects of unconventional policies on the cost of borrowing 
for NFCs in the eurozone. This empirical analysis is based on the estimation of the following equation for each country. ${ }^{12}$

$$
\Delta Y_{t}=\alpha+\beta P N C_{t-1}+\gamma C_{t-1}+\sum_{n=1}^{N} \eta_{n} \Delta Y_{t-n}+\varepsilon_{t}
$$

where $Y_{t}$ is the real cost of credit to companies, $P N C_{t}$ is the set of unconventional policies, $C_{t}$ is a set of control variables and $\varepsilon_{t}$ is the residual term. We focus on the changes in financing conditions, as first difference $(\Delta)$. This allows for work on stationary series. The cost of credit is a composite indicator based on lending interest rates, calculated by the ECB. This measure is used to evaluate the costs of borrowing for non-financial companies. It is useful for international comparisons.

In terms of indicators of unconventional monetary policy, there are few alternatives. The size of the Central Bank's balance sheet constitutes an imperfect measure. It could lead one to believe that the ECB has been much less resourceful since the end of 2013 (cf. figure C1-III, online complement C1) but this is not the case (it all depends on the needs of investors). Furthermore, such an indicator does not fully reflect the impact of qualitative measures such as the collateral easing. Additionally, the shadow rate, ${ }^{13}$ sometimes used in the literature, is not useful to our analysis in that it is meant to reflect the monetary conditions inclusing both conventional monetary policy and unconventional policy measures. But, with our objective being to identify the direct and indirect effects, it is important here to properly distinguish between the two types of policy. Finally, to only consider the outstanding amount of LTROs or MROs, as it is sometimes the case in the literature, would be reductive. That is why we preferred to represent each measure of unconventional policy through dummy variables which take the value 1 over the course of the period of their implementation. The dates corresponding to each announcement and implementation are given in table $\mathrm{C} 1-1$ (online complement $\mathrm{C} 1$ ).

The control variables are used in equation (1) to limit the bias of omitted variables. We consider the EONIA (Euro OverNight Index Average) and other variables related to the different crises or the vulnerability of the eurozone (Crisis, Public Deficit, Public Debt) and aggregate demand (BLS, IPI). All control variables are lagged in order to limit simultaneity bias.
The list of variables, their definitions and their sources are given in table 1. Table C1-3 (in online complement $\mathrm{C} 1$ ) provides summary statistics relating to the variables considered in this article. The estimations cover the period from January 2003 to December 2014 over the 11 countries. Equation (1) is estimated by the ordinary least squares method on monthly data, ${ }^{14}$ with an adjustment of the variance of the estimators using the Newey-West approach. Over the course of the estimation period the EONIA varied between $-0.03 \%$ and $4.3 \%$ with an average of $1.62 \%$.

An unconventional policy measure is said to be effective if $\beta^{\prime}=\beta /\left(1-\sum_{n=1}^{N} \eta_{n}\right)$ is negative. This hypothesis reflects the fact that unconventional policies relax the financing conditions of economic investors. If the opposite occurred the unconventional policies is not effective in terms of reducing the borrowing cost. ${ }^{15}$

The results of our estimations are given in table 2 . We find that only four programmes were effective, in six countries. A significant effect arises from the procedure of fixed-rate full allotment (FRFA), longer-term refinancing operations (LTROs), the collateral easing (Collateral) and the purchase of covered bonds (Covered). The most effective programmes are the FRFAs and LTROs. These two measures have helped to reduced the real cost of credit in Belgium, Germany, Spain, Greece, Ireland and Portugal. The collateral easing has been effective only in Spain. Furthermore, the purchase of covered bonds has had the expected effects in Portugal. However, there is no visible impact, in terms of reducing the cost of credit, of foreign currency swaps, Outright Monetary Transactions (OMTs), nor of the purchase programme of public and private assets (SMP).

According to these results, on the one hand, the provision of liquidity (LTROs and FRFAs) are the most effective with regards to reducing

12. Simplified writing: $\beta$ includes the respective effect of each instrument of unconventional policy (UMP); likewise for $\gamma$ relative to each control variable $C$.

13. The shadow rate is a theoretical rate based on a modelling of the yield curve incorporating a short term rate which could be negative (Wu $\&$ Xia, 2016). By design, this rate reports on both unconventional policies and rates policy.

14. The quarterly variables, namely the indicator of BLS demand, public deficit and public debt, are presumed to be consistent over the course of the months making up the quarter.

15. Sometimes even the implementation of certain programmes played a revelatory role regarding the gravity of the situation. So much so that the effect of a measure may be contrary to the expected signal. This is if the signalling (cf. online complement) was reversed. 
the real cost of credit. On the other hand, Spain and Portugal have benefited the most from the programmes relating to the reduction of the real cost of borrowing to NFCs.

A priori, the other programmes did not appear to have a significant impact on the reduction of the cost of financing to NFCs. This is notably the case for collateral easing (with the exception of Spain). It is important to note, however, that foreign currency swaps targeted less credit conditions than banks' cross-border activities. Likewise, the SMP and OMT programmes, put in place to fight the sovereign debt crisis in the eurozone, aimed to reduce sovereign spreads.

The finally very limited effect of unconventional policies on the cost of financing explains why the ECB needed to implement different measures and programmes. Then, whereas the Fed began to shift away from the UMPs in 2016, the ECB announced new measures (TLTRO II). However, we have so far only considered the direct effects of unconventional measures. Yet these measures also aim to restore the transmission of (conventional) rates policy, starting with zero rates policy (Antonin et al., 2014).
Therefore, they could have had indirect effects which we test next.

\section{Indirect effects of unconventional policies on the cost of credit}

To measure the indirect effects, equation (1) is modified so as to take into account the extra effect of the EONIA on financing conditions, conditional to the implementation of unconventional policies. This conditionality is modelled in the form of an interaction in the following estimated equation:

$$
\begin{aligned}
\Delta Y_{t}= & \alpha+\beta_{0} \Delta R_{t-1}+\beta_{1} \Delta R_{t-1} * B_{t-1} \\
& +\gamma C_{t-1}+\sum_{n=1}^{N} \eta_{n} \Delta Y_{t-n}+\varepsilon_{t}
\end{aligned}
$$

where $B_{t}$ is the central bank's balance sheet growth rate (in \% of GDP).

The endogenous and exogenous variables are the same as those presented in table 1 . The coefficient $\beta_{0}$ captures the direct effect of the EONIA interest rate (written as $R_{t}$ ) on $Y_{t}$.

Table 1

\begin{tabular}{|c|c|c|}
\hline Variable & Definition & Sources \\
\hline \multicolumn{3}{|c|}{ Dependent variable $(Y)$} \\
\hline Y & Difference between "Cost of Borrowing" and "Inflation" & ECB \\
\hline \multicolumn{3}{|c|}{ Explanatory variables } \\
\hline \multicolumn{3}{|l|}{ UP } \\
\hline FRFA & Dummy = 1 during the implementation of the policy of fixed-rate full allotment & Cf. Table C1-1 \\
\hline LTRO & Dummy $=1$ during the implementation of the policy of longer-term financing operations, otherwise 0 & idem \\
\hline Swap & Dummy = 1 during the implementation of the policy of provisions in foreign currency, otherwise 0 & id. \\
\hline Collateral & Dummy = 1 during the implementation of the policy of easing of guarantee conditions, otherwise 0 & id. \\
\hline SMP & $\begin{array}{l}\text { Dummy = } 1 \text { during the implementation of the Government and private sector securities purchases, } \\
\text { otherwise } 0\end{array}$ & id. \\
\hline OMT & Dummy = 1 during the implementation of the policy of Outright Monetary Transactions & id. \\
\hline Covered & Dummy = 1 during the implementation of the policy of covered bond purchases, otherwise 0 & id. \\
\hline \multicolumn{3}{|c|}{ Control variables $(C)$} \\
\hline EONIA & Euro OverNight Index Average (daily rate) & Macrobond \\
\hline Crisis & Dummy showing banking and sovereign debt crises & Szczerbowicz (2015) \\
\hline BLS & Bank Lending Survey demand & ECB \\
\hline Deficit & Public Deficit/Surplus (in \% of GDP) & Eurostat \\
\hline Debt & Public debt in \% of GDP & Eurostat \\
\hline IPI & Industrial Production Index & Eurostat \\
\hline
\end{tabular}

Definitions and sources of variables

Note: This table presents the dependent variable and the explanatory variables of equation (1), their definitions, the abbreviations retained in the empirical analysis, and their sources. The cost of borrowing is a harmonised indicator constructed by the ECB and inflation is calculated as the monthly growth rate of the Harmonised Index of Consumer Prices. 
The parameter $\beta_{1}$ measures the extra effect of the EONIA daily rate, attributable to the expansion of the central bank's balance sheet. Firstly, in order to ensure that we are properly capturing in this way the indirect effects of unconventional measures, relation (2) is estimated over two sub-periods which correspond to two distinct regimes of monetary policy: the period before the implementation of unconventional policies (January 2003-March 2007) and the period corresponding to the implementation of unconventional measures (January 2008-December 2014). Also, with the objective being to highlight the complementarity between unconventional policies and rates policy, only the parameter $\beta_{1}^{\prime}$ defined as $\beta_{1}^{\prime}=\beta_{1} /\left(1-\sum_{n=1}^{N} \eta_{n}\right)$ will be shown in table 3. According to the hypothesis of restoring the effects of unconventional monetary policy, the expected signal of $\beta_{1}$ is positive.
According to the first two columns ("Before" and "After" in table 3), it arises that before 2008 the size of the balance sheet does not influence the impact of the interest rate on financing conditions. This is consistent with the absence of unconventional policy. The balance sheet then had no active role. However, from January 2008 (cf. "After" column), the central bank actively used its balance sheet (size and composition) to guide its low-rate policy. The additional effect of the size of the balance sheet is greater in Spain, the Netherlands and Portugal. It is less significant in Belgium and Germany. Except for Finland, France and Ireland, the size of the balance sheet therefore played a role in the transmission of rates policy during the crisis. We thus validate the existence of indirect effects in their entirety.

Now, by following the same method as in the preceding section, we will evaluate more specifically the indirect effects of each of the

Table 2

Indirect effects of unconventional policies on the real cost of credit

\begin{tabular}{|c|c|c|c|c|c|c|c|}
\hline & FRFA & LTRO & Swap & Collateral & OMT & SMP & Covered \\
\hline \multirow[t]{2}{*}{ Austria } & -0.088 & -0.023 & 0.060 & 0.006 & -0.020 & 0.024 & 0.030 \\
\hline & $(0.076)$ & $(0.051)$ & $(0.080)$ & $(0.068)$ & $(0.038)$ & $(0.038)$ & $(0.042)$ \\
\hline \multirow[t]{2}{*}{ Belgium } & -0.007 & $-0.086^{*}$ & 0.102 & 0.018 & 0.039 & $0.071^{\text {** }}$ & -0.001 \\
\hline & $(0.032)$ & $(0.048)$ & $(0.066)$ & $(0.039)$ & $(0.037)$ & $(0.035)$ & $(0.026)$ \\
\hline \multirow[t]{2}{*}{ Germany } & $-0.126^{* *}$ & $-0.087^{* *}$ & 0.067 & -0.028 & -0.002 & 0.029 & -0.014 \\
\hline & $(0.057)$ & $(0.040)$ & $(0.060)$ & $(0.044)$ & $(0.032)$ & $(0.026)$ & $(0.027)$ \\
\hline \multirow[t]{2}{*}{ Spain } & $-0.363^{* * *}$ & $-0.205^{\star *}$ & 0.175 & $-0.230^{*}$ & $0.176^{\star}$ & 0.013 & -0.036 \\
\hline & $(0.116)$ & $(0.102)$ & $(0.119)$ & $(0.125)$ & $(0.094)$ & $(0.069)$ & $(0.075)$ \\
\hline \multirow[t]{2}{*}{ Finland } & -0.023 & 0.035 & 0.062 & 0.036 & 0.039 & 0.012 & -0.025 \\
\hline & $(0.048)$ & $(0.073)$ & $(0.075)$ & $(0.041)$ & $(0.048)$ & $(0.029)$ & $(0.034)$ \\
\hline \multirow[t]{2}{*}{ France } & -0.146 & -0.054 & $0.104^{* *}$ & 0.013 & -0.023 & $0.047^{*}$ & 0.012 \\
\hline & $(0.108)$ & $(0.045)$ & $(0.050)$ & $(0.035)$ & $(0.050)$ & $(0.028)$ & $(0.030)$ \\
\hline \multirow[t]{2}{*}{ Greece } & $-0.273^{* *}$ & -0.074 & $0.153^{*}$ & -0.043 & -0.084 & $0.133^{* *}$ & -0.048 \\
\hline & $(0.116)$ & $(0.097)$ & $(0.086)$ & $(0.091)$ & $(0.085)$ & $(0.064)$ & $(0.045)$ \\
\hline \multirow[t]{2}{*}{ Ireland } & $-0.170^{*}$ & -0.122 & 0.108 & -0.020 & 0.020 & 0.029 & -0.032 \\
\hline & $(0.101)$ & $(0.076)$ & $(0.070)$ & $(0.056)$ & $(0.057)$ & $(0.036)$ & $(0.043)$ \\
\hline \multirow[t]{2}{*}{ Italy } & 0.002 & -0.070 & $0.179^{*}$ & -0.029 & -0.134 & 0.112 & 0.058 \\
\hline & $(0.138)$ & $(0.086)$ & $(0.105)$ & $(0.103)$ & $(0.162)$ & $(0.084)$ & $(0.073)$ \\
\hline \multirow[t]{2}{*}{ The Netherlands } & -0.008 & -0.029 & $0.125^{\star *}$ & 0.036 & 0.057 & 0.045 & -0.062 \\
\hline & $(0.075)$ & $(0.050)$ & $(0.059)$ & $(0.057)$ & $(0.060)$ & $(0.042)$ & $(0.041)$ \\
\hline \multirow[t]{2}{*}{ Portugal } & $-0.202^{* * *}$ & $-0.101^{*}$ & 0.066 & 0.019 & -0.075 & $0.115^{\star *}$ & $-0.069^{*}$ \\
\hline & $(0.074)$ & $(0.059)$ & $(0.082)$ & $(0.066)$ & $(0.075)$ & $(0.046)$ & $(0.037)$ \\
\hline
\end{tabular}

Note: This table reports the coefficients $\beta^{\prime}$ in each country and for each instrument of unconventional monetary policy. A negative and significant value of $\beta^{\prime}$ validates the direct effects of the measure concerned in the country concerned. The estimations are carried out over the period January 2003 to December 2014 by using the Newey-West approach with a lag of order $N=3 \equiv\left[T^{0.25}\right]$. The standard errors are indicated in brackets *** Significant at $1 \%,{ }^{* *}$ Significant at $5 \%$, et * Significant at $10 \%$.

Sources: Authors' estimations. 
unconventional effects. To this end, we proceed with the estimation of the following relation:

$$
\begin{aligned}
\Delta Y_{t}= & \alpha+\beta_{0} \Delta R_{t-1}+\beta_{1} \Delta R_{t-1} * P N C_{t-1} \\
& +\beta_{2} P N C_{t-1}+\gamma C_{t-1}+\sum_{n=1}^{N} \eta_{n} \Delta Y_{t-n}+\varepsilon_{t}
\end{aligned}
$$

The endogenous and exogenous are the same as those presented in table 1 . The coefficient $\beta_{0}$ captures the direct effect of the EONIA interest rate (written as $R_{t}$ ) on $Y_{t}$, whereas $\beta_{1}$ measures the extra effect of the EONIA daily rate, attributable to the implementation of unconventional measures. The results of the estimations are detailed in the columns from "FRFA" to "Covered" in table 3.

We notice (in comparison with table 2) that the indirect effects are more compelling than the direct effects. Each measure has had a significant effect on the costs of borrowing in at least one country. Specifically, the FRFA procedure has helped to reduce the cost of credit in Austria, Belgium, Germany, Spain and Portugal. The effects are comparatively greater in Portugal. The effectiveness of this measure could be explained by its duration. It was introduced in October 2008 and has been regularly renewed to this date in order to bring in the necessary liquidity to the banking sector. Our result is in the same line as those of Antonin et al. (2014) and Creel et al. (2016).

The policies of asset purchasing (SMP and Covered) have also contributed to the decline of the borrowing cost (in Austria, Germany, Spain, Finland, France, Greece, Italy) with more considerable effects in countries such as Spain and Italy. These measures, by further relaxing banks'

Table 3

\begin{tabular}{|c|c|c|c|c|c|c|c|c|c|}
\hline & Before & After & FRUA & LTRO & Swap & Collateral & OMT & SMP & Covered \\
\hline Austria & $\begin{array}{l}-0.148 \\
(0.656)\end{array}$ & $\begin{array}{l}0.702^{*} \\
(0.406)\end{array}$ & $\begin{array}{l}0.119^{*} \\
(0.067)\end{array}$ & $\begin{array}{c}0.016 \\
(0.050)\end{array}$ & $\begin{array}{l}0.164^{* *} \\
(0.076)\end{array}$ & $\begin{array}{l}0.210^{\star *} \\
(0.099)\end{array}$ & $\begin{array}{l}2.327^{\star \star *} \\
(0.805)\end{array}$ & $\begin{array}{l}0.646^{* *} \\
(0.316)\end{array}$ & $\begin{array}{l}0.543^{* *} \\
(0.265)\end{array}$ \\
\hline Belgium & $\begin{array}{c}0.224 \\
(1.527)\end{array}$ & $\begin{array}{c}0.446^{\star \star \star} \\
(0.157)\end{array}$ & $\begin{array}{l}0.100^{*} \\
(0.057)\end{array}$ & $\begin{array}{l}-0.030 \\
(0.042)\end{array}$ & $\begin{array}{c}0.094 \\
(0.060)\end{array}$ & $\begin{array}{c}0.241^{* * *} \\
(0.075)\end{array}$ & $\begin{array}{c}0.271 \\
(0.624)\end{array}$ & $\begin{array}{c}0.283 \\
(0.238)\end{array}$ & $\begin{array}{l}0.100 \\
(0.240)\end{array}$ \\
\hline Germany & $\begin{array}{l}0.235 \\
(0.808)\end{array}$ & $\begin{array}{c}0.376^{\star * *} \\
(0.107)\end{array}$ & $\begin{array}{l}0.111^{\star \star *} \\
(0.035)\end{array}$ & $\begin{array}{c}0.007 \\
(0.026)\end{array}$ & $\begin{array}{c}0.083 \\
(0.062)\end{array}$ & $\begin{array}{l}0.185^{\star \star \star} \\
(0.057)\end{array}$ & $\begin{array}{c}0.188 \\
(0.538)\end{array}$ & $\begin{array}{l}0.479^{* *} \\
(0.204)\end{array}$ & $\begin{array}{l}0.303^{*} \\
(0.171)\end{array}$ \\
\hline Spain & $\begin{array}{c}2.157 \\
(2.001)\end{array}$ & $\begin{array}{l}1.888^{* * *} \\
(0.680)\end{array}$ & $\begin{array}{l}0.132^{\star} \\
(0.069)\end{array}$ & $\begin{array}{c}0.080 \\
(0.060)\end{array}$ & $\begin{array}{c}0.029 \\
(0.106)\end{array}$ & $\begin{array}{l}0.207^{*} \\
(0.113)\end{array}$ & $\begin{array}{c}1.702 \\
(1.124)\end{array}$ & $\begin{array}{l}1.351^{* *} \\
(0.560)\end{array}$ & $\begin{array}{l}1.212^{\star * *} \\
(0.428)\end{array}$ \\
\hline Finland & $\begin{array}{l}-0.653 \\
(1.127)\end{array}$ & $\begin{array}{l}0.169 \\
(0.379)\end{array}$ & $\begin{array}{l}-0.033 \\
(0.092)\end{array}$ & $\begin{array}{l}-0.051 \\
(0.063)\end{array}$ & $\begin{array}{c}0.001 \\
(0.121)\end{array}$ & $\begin{array}{l}0.144^{* *} \\
(0.056)\end{array}$ & $\begin{array}{l}0.395 \\
(0.659)\end{array}$ & $\begin{array}{l}-0.149 \\
(0.284)\end{array}$ & $\begin{array}{c}0.641^{* * *} \\
(0.248)\end{array}$ \\
\hline France & $\begin{array}{l}-0.557 \\
(0.797)\end{array}$ & $\begin{array}{c}0.291 \\
(0.195)\end{array}$ & $\begin{array}{l}0.076 \\
(0.050)\end{array}$ & $\begin{array}{l}-0.036 \\
(0.046)\end{array}$ & $\begin{array}{l}0.094^{*} \\
(0.057)\end{array}$ & $\begin{array}{c}0.118 \\
(0.076)\end{array}$ & $\begin{array}{l}-0.111 \\
(0.636)\end{array}$ & $\begin{array}{c}0.062 \\
(0.239)\end{array}$ & $\begin{array}{c}0.539^{\star * *} \\
(0.203)\end{array}$ \\
\hline Greece & $\begin{array}{l}-0.439 \\
(1.578)\end{array}$ & $\begin{array}{l}0.705^{\star} \\
(0.388)\end{array}$ & $\begin{array}{l}0.081 \\
(0.054)\end{array}$ & $\begin{array}{c}0.024 \\
(0.034)\end{array}$ & $\begin{array}{c}0.039 \\
(0.094)\end{array}$ & $\begin{array}{c}0.092 \\
(0.136)\end{array}$ & $\begin{array}{l}-2.160 \\
(1.412)\end{array}$ & $\begin{array}{l}0.931^{\text {** }} \\
(0.395)\end{array}$ & $\begin{array}{c}0.945 \\
(0.664)\end{array}$ \\
\hline Ireland & $\begin{array}{c}2.003 \\
(1.475)\end{array}$ & $\begin{array}{c}0.086 \\
(0.740)\end{array}$ & $\begin{array}{l}0.045 \\
(0.051)\end{array}$ & $\begin{array}{c}0.009 \\
(0.053)\end{array}$ & $\begin{array}{c}0.043 \\
(0.063)\end{array}$ & $\begin{array}{l}-0.044 \\
(0.068)\end{array}$ & $\begin{array}{l}-0.329 \\
(0.705)\end{array}$ & $\begin{array}{c}0.435 \\
(0.296)\end{array}$ & $\begin{array}{c}0.054 \\
(0.228)\end{array}$ \\
\hline Italy & $\begin{array}{l}-0.815 \\
(1.474)\end{array}$ & $\begin{array}{l}0.892^{\star *} \\
(0.381)\end{array}$ & $\begin{array}{c}0.180 \\
(0.125)\end{array}$ & $\begin{array}{l}0.134^{* *} \\
(0.062)\end{array}$ & $\begin{array}{l}-0.050 \\
(0.071)\end{array}$ & $\begin{array}{l}0.041 \\
(0.258)\end{array}$ & $\begin{array}{l}4.249^{\star *} \\
(1.751)\end{array}$ & $\begin{array}{l}0.960^{*} \\
(0.550)\end{array}$ & $\begin{array}{l}1.240^{* *} \\
(0.603)\end{array}$ \\
\hline The Netherlands & $\begin{array}{c}2.499 \\
(1.527)\end{array}$ & $\begin{array}{l}1.322^{\star \star \star} \\
(0.302)\end{array}$ & $\begin{array}{l}-0.052 \\
(0.111)\end{array}$ & $\begin{array}{l}-0.025 \\
(0.032)\end{array}$ & $\begin{array}{c}0.085 \\
(0.058)\end{array}$ & $\begin{array}{c}0.299^{\star * *} \\
(0.109)\end{array}$ & $\begin{array}{l}-1.174 \\
(0.955)\end{array}$ & $\begin{array}{c}0.154 \\
(0.361)\end{array}$ & $\begin{array}{c}0.256 \\
(0.304)\end{array}$ \\
\hline Portugal & $\begin{array}{c}5.342 \\
(3.257)\end{array}$ & $\begin{array}{l}1.635^{\star *} \\
(0.698)\end{array}$ & $\begin{array}{c}0.241^{\star \star *} \\
(0.040)\end{array}$ & $\begin{array}{c}0.025 \\
(0.068)\end{array}$ & $\begin{array}{c}0.074 \\
(0.058)\end{array}$ & $\begin{array}{c}0.261^{\star * *} \\
(0.068)\end{array}$ & $\begin{array}{c}0.284 \\
(1.124)\end{array}$ & $\begin{array}{c}0.434 \\
(0.350)\end{array}$ & $\begin{array}{l}-0.114 \\
(0.197)\end{array}$ \\
\hline
\end{tabular}

Indirect effects of non-conventional policies on the real cost of credit

Note: This table reports the coefficients $\beta_{1}^{\prime}$ in each country and for each instrument of unconventional monetary policy. The two columns "Before" and "After" present the coefficients $\beta$ ' taken from equation (2) estimated respectively over the periods January 2003-March 2007 and January 2008-December 2014. The other columns report the coefficients $\beta_{1}^{\prime}$ taken from equation (3) estimated over the period January 2003-December 2014. A positive and significant value of $\beta_{1}^{\prime}$ indicates that the expansion of the balance sheet or the unconventional measures mentioned have helped to restore the transmission of rates policy. All the coefficients are obtained by using the Newey-West approach with a lag of order $N=3 \equiv\left[T^{0.25}\right]$. The standard errors are indicated in brackets. ${ }^{* *}$ Significant at $1 \%$, ${ }^{*}$ Significant at $5 \%$, et * Significant at $10 \%$.

Sources: Authors' estimations. 
financing constraint, allowed them to more quickly adjust downward the costs of borrowing for companies. The collateral easing (Collateral) was one of the most effective measures with regards to the transmission of monetary policy, while the effects of LTROs and OMTs are limited to a few countries. Also, by facilitating access to liquidity, the relaxation of guarantee conditions helped the transmission of rates policy in the eurozone. We see that certain countries, such as Greece, the Netherlands, Portugal and Ireland, have benefited less from the effects of the measures of unconventional monetary policy. In fact, in Greece and Ireland, the banking system has survived thanks to liquidity provisions granted by the national central banks within the Emergency Liquidity Assistance framework.

\section{How might the heterogeneity of the effect of unconventional measures be explained?}

The structural differences within the eurozone have already explained divergences of reactions to the "conventional" monetary policy impulse. These divergences typically concern the periods of adjustment of bank rates (Leroy \& Lucotte, 2016; Mojon, 2001). The most liquid or best-capitalised banks adjust their rates more slowly (Sorensen \& Werner, 2006), whereas those exposed to very high credit risk adjust more quickly (Valverde \& Fernández, 2007). The short-term economic characteristics (growth, housing price inflation, credit growth) also tend to influence the adjustment of bank rates (Sorensen \& Werner, 2006).

From this viewpoint, we study in an original way the heterogeneity of the indirect effects of unconventional policies. The idea is precisely to evaluate the impact of rates policy conditional to certain structural and short-term characteristics of the economies studied, when unconventional measures are being implemented. To this end, we used a panel conditionally homogeneous VAR model (PCHVAR), following the method proposed by Georgiadis (2014). This model is written in the following way:

$y_{i t}=\delta_{i}+\sum_{j=1}^{p} A_{j}\left(z_{i t}\right) y_{i, t-j}+u_{i t}$

where $y_{i t}=[\text { Real cost of credit, EONIA }]^{\prime}$ is the $2 \times 1$ vector of the endogenous variables, $\delta_{i}$ represents the fixed effects, $u_{i t}$ is the vector of the residuals that follow a normal distribution with zero mean and of variance $\Sigma_{u, i}, i=1, \ldots, N$ represents the country and $t=1, \ldots, T$ the time.
The originality of the approach lies on to the fact that the $2 \times 2$ matrix of parameters $A_{j}\left(z_{i t}\right)$ of the VAR depend on conditioning variables, $z_{i t}$. As the latter are different from one country to another, and also change over time, the parameters $A_{j}\left(z_{i t}\right)$ of the VAR themselves are country specific and are time-varying. This conditionality of the parameters $A_{j}\left(z_{i t}\right)$ to the variables $z_{i t}$ allows for the measurement of the potential heterogeneity of the transmission of unconventional monetary policy instruments. So, generally, if the realisations $z_{i t}$ and $z_{j t}$ are identical for two countries $i$ and $j$, we shall say that the dynamic in the transmission of monetary policy is conditionally homogeneous in these two countries.

The procedure applied is the following. The VAR model specified in equation (4) is estimated for a given variable $z_{j}$. The matrices of the estimated parameters $\hat{A}($.$) depend on z_{j}$. We suppose that each element of $a_{j, s m}\left(z_{i t}\right)$ of $A_{j}($.) can be written in the form $a_{j, s m}\left(z_{i t}\right) \approx \pi\left(z_{i t}\right) \gamma_{j, s m}$, with $s$ and $m$ respectively the lines and columns of $A_{j}(),. \pi$ is a polynomial of order one in $z$ and $\gamma$ the associated coefficient. The vector moving average (VMA) form of the model, which defines the impulse response functions (IRFs) of the model, is thus also conditional to $z_{j}$. It is possible, then, to plot the IRFs conditional to several values taken successively in the distribution of $z_{j}$; we focus particularly on its minimum value, its median value, and to the value corresponding to the last decile. We can also more closely examine whether the responses of the cost of credit to an increase of a standard deviation of the EONIA are sensitive to the characteristic $z_{j}$ considered. The orthogonal impulse responses follow Cholesky's decomposition method.

Table 4 presents the conditioning variables $(z)$ used and their sources. Summary statistics of these variables are provided in table C2-1 (online complement $\mathrm{C} 2$ ). The estimations cover the period September 2008 - December 2014. So, as well as considering the variables of conditioning $z_{j}$, the responses obtained must be understood conditionally to the ECB's implementation of unconventional measures of monetary policy over this period. In line with the results from the preceding section, the response functions offer interpretations to the heterogeneity of the indirect effects of unconventional policy measures. Finally, in general, the responses to the monetary policy shock (IRFs) are appreciated with regards to their magnitude and the number of periods during which they are significantly different from zero. 


\section{Influence of the macro-financial environment}

Firstly, we examine the sensitivity of the indirect effects of the ECB's unconventional monetary policy to the economic outlook. In this respect, figure I presents the responses of the total cost of borrowing, in a period of crisis, following a monetary policy shock, dependent on GDP growth. These responses are framed by a confidence interval at $95 \%$.

The first dial represents the response of the cost of credit to a shock of +1 standard deviation of the EONIA rate, when the growth rate corresponds to the minimum observed over the course of the estimation period. The second (third) dial conveys the same information, but this time when the growth rate corresponds to the median value (the third one, respectively to the last decile) observed between September 2008 and December 2014. We notice that the higher the economy's growth rate, the greater the response of the cost of credit to the EONIA rate. Unconventional monetary policies would have thus benefited more the economies less affected by the crisis in terms of growth. De Bondt (2002) and Leroy and Lucotte (2016) also find a degradation of the pass-through in a time of bad economic outlook.
The probabilities of default constitute another factor likely to affect pass-through. In fact, the greater the probabilities of default in the economy, the more banks will tend to lend less (potentially going as far as rationing) rather than to pass the short rate variations on lending rates (Leroy \& Lucotte, 2016). Figure II actually shows that the impact of monetary policy is declining, in magnitude and duration, as companies' probability of default increases.

With regard to the period covered, the influence of public debt is worth consideration. We observe that the response of the cost of credit to the EONIA rate decreases in magnitude with the level of debt on GDP (see figure III). The link is even broken between EONIA and the cost of credit for the levels of public debt which correspond to the last decile.

In other words, unconventional monetary policy measures would have been less effective where public debt was high, like in Greece or Italy. In this case, all other things being equal, they would not have been enough to connect the cost of credit to the short-term interest rate. In the same line of thinking, figure C2-I (in online complement $\mathrm{C} 2$ ) indicates that the response of the borrowing cost to monetary

Table 4

Definitions and sources of conditional variables

\begin{tabular}{|c|c|c|}
\hline Indicator & Description & Sources \\
\hline \multicolumn{3}{|c|}{ Macro-financial environment } \\
\hline Debt & Public debt (\% of GDP) & Eurostat \\
\hline Growth & Economy's growth rate & OECD \\
\hline Premium & Sovereign premium & Macrobond \\
\hline PD & Economy's probability of default & $\mathrm{CRI}$ \\
\hline CISS & Composite Indicator of Systemic Stress & ECB \\
\hline \multicolumn{3}{|c|}{ Importance of the health of the banking sector } \\
\hline Capitalisation & Banks' Capital and Reserves over GDP & ECB \\
\hline Size & Total company credit (\% of GDP) & ECB \\
\hline Liquidity & Total household deposits over GDP & ECB \\
\hline NPL & Banks' non-performing loans (\% of total loans) & GFDD \\
\hline \multicolumn{3}{|c|}{ Financial structure of economies } \\
\hline Concentration & Herfindahl-Hirschman index & ECB \\
\hline Competition & Lerner index & GFDD \\
\hline Stock market capitalisation & Value of listed shares (in \% of GDP) & GFDD \\
\hline
\end{tabular}

Note: This table presents the conditional variables used successively in equation (4), their definitions, their abbreviations and their sources. The sovereign premium is defined by the spread of the national 10 year rates with the German rate of the same maturity. For Germany, the reference is the American 10 year rate.

The series of GDP have been split into months drawing on Denton's proportional method (see chapter 6 of Bloem et al., 2001). We consider the year-on-year growth rate. The economy's probability of default corresponds to the aggregate probability of default for all the companies: banks, financial establishments and industrial businesses. 
policy impulse declines with the level of sovereign premiums, defined by the spread of national 10 year rates with the German rate of the same maturity. A similar result was obtained by Leroy et Lucotte (2016) with an Interacted Panel VAR (IPVAR).
Finally, the effects of monetary policy were influenced by the level of systemic risk (Altunbas et al., 2009, 2010), measured here by the composite indicator of systemic stress, CISS (which grows with overall risk), constructed by the ECB. Again, we observe that the

Figure I

Responses of the borrowing cost to an EONIA shock and conditional to economic growth

Minimum value of growth rate

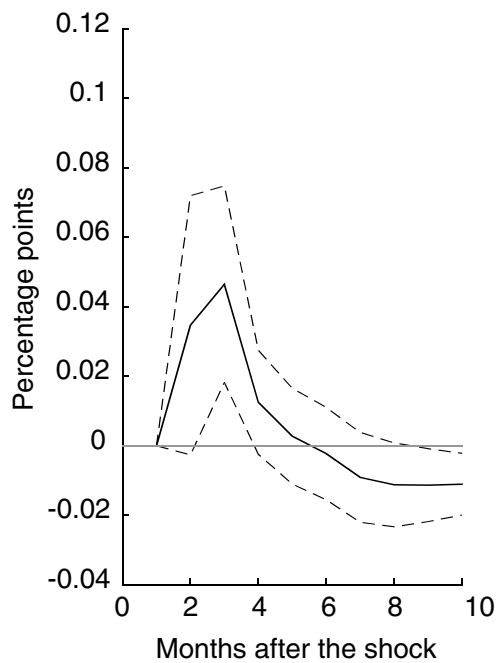

Median value of growth rate

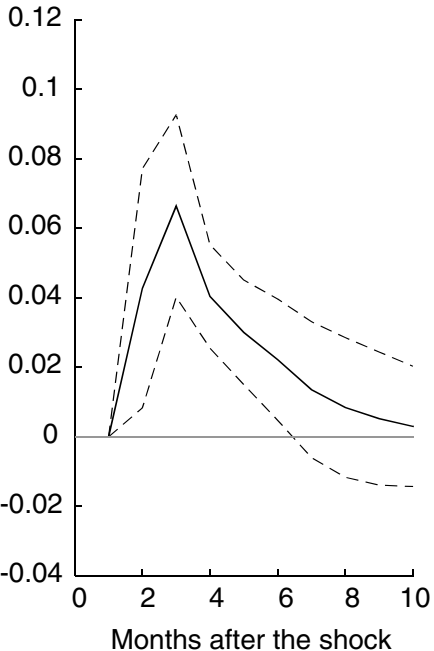

$90^{\text {th }}$ percentile of growth rate

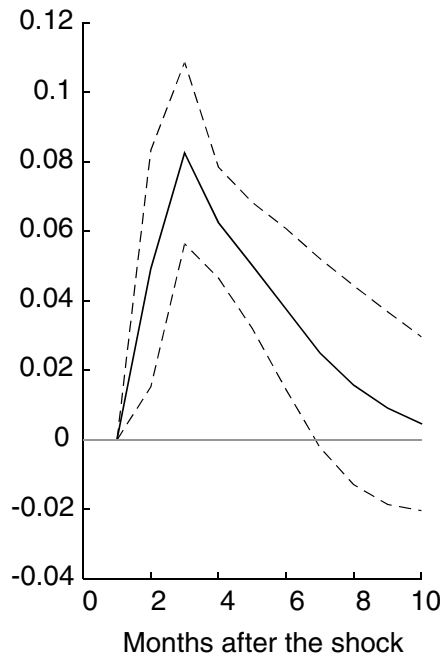

Note: These graphs represent the responses of the real borrowing cost following a shock of +1 standard deviation of the EONIA rate conditional to GDP growth. Model (4) is estimated over the period September 2008 to December 2014. We consider the minimum value, the median and the $90^{\text {th }}$ percentile of GDP growth rate over the estimation period. The solid line corresponds to the estimated response while the dotted lines represent the $95 \%$ confidence interval.

Figure II

Responses of the borrowing cost to an EONIA shock conditional to the probability of default
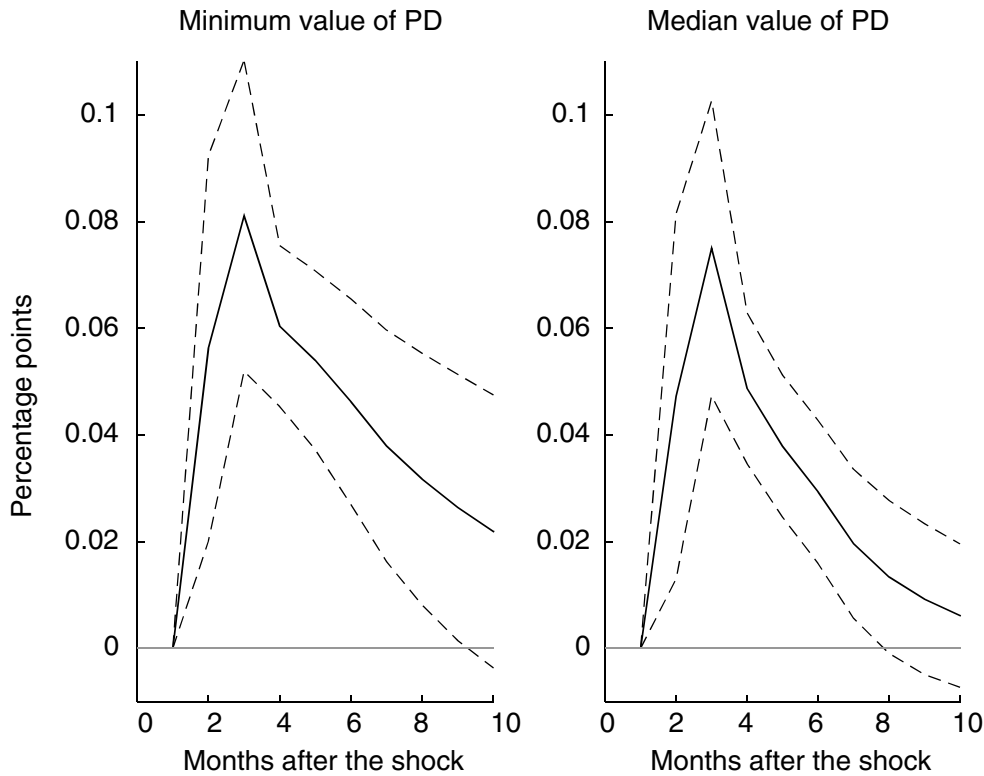

$90^{\text {th }}$ percentile of PD

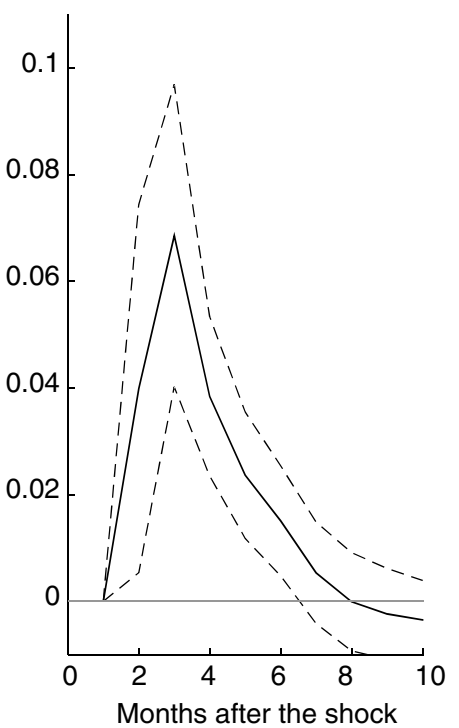

Note: These graphs represent the responses of the real borrowing cost following a shock of +1 standard deviation of the EONIA rate conditional to the aggregate probability of default for all the companies. The model is estimated over the period September 2008 to December 2014 . We consider the minimum value, the median and the $90^{\text {th }}$ percentile of the probability of default over the estimation period The solid line corresponds to the estimated response while the dotted lines represent the $95 \%$ confidence interval 
responses are not homogeneous with respect to the systemic risk. The higher the systemic risk, the more pass-through is weakened (figure IV).
Banks' level of exposure to risk might have acted negatively on their propensity to grant loans (Gambacorta \& Marques-Ibanez, 2011),

Figure III

Responses of the borrowing cost to an EONIA shock conditional to public debt

Minimum value of debt

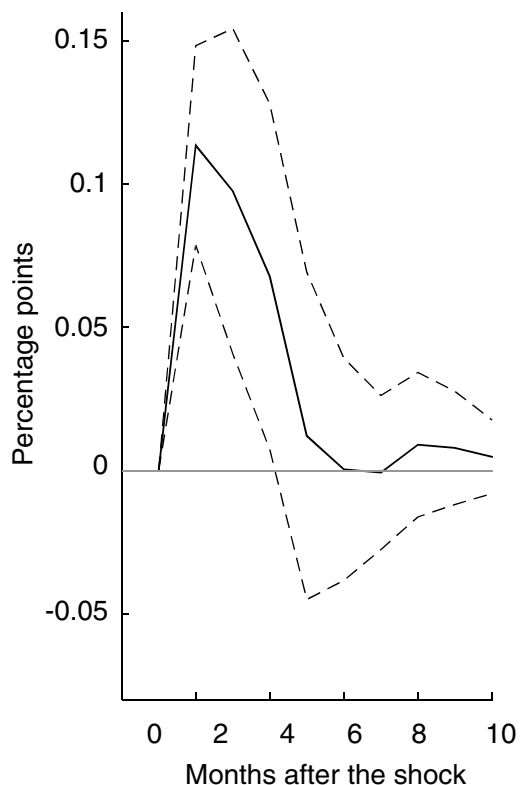

Median value of debt

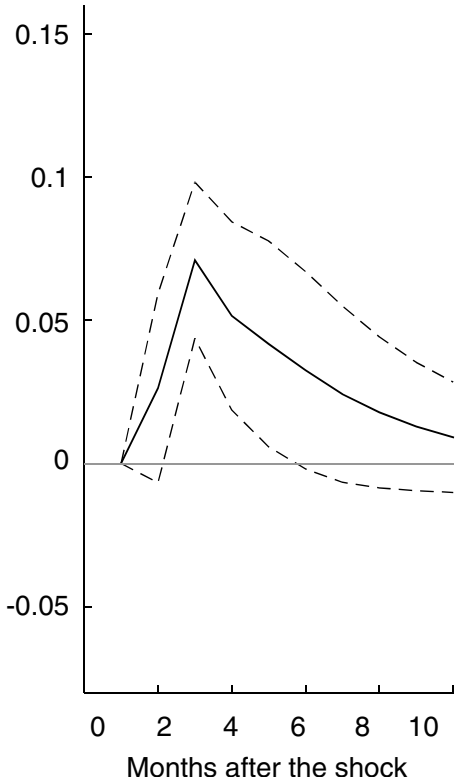

$90^{\text {th }}$ percentile of debt

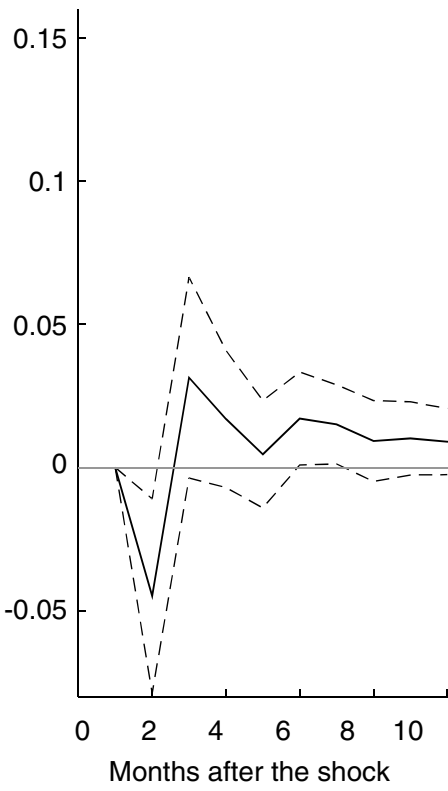

Note: These graphs are the responses of the real borrowing cost following a shock of +1 standard deviation of the EONIA rate conditional to the ratio of public debt over GDP. The model is estimated over the period September 2008 to December 2014. We consider the minimum value, the median and the $90^{\text {th }}$ percentile of the ratio of public debt over GDP over the estimation period. The solid line is the estimated response while the dotted lines represent the $95 \%$ confidence interval.

Figure IV

Responses of the borrowing cost to an EONIA shock conditional to systemic risk

Minimum value of CISS

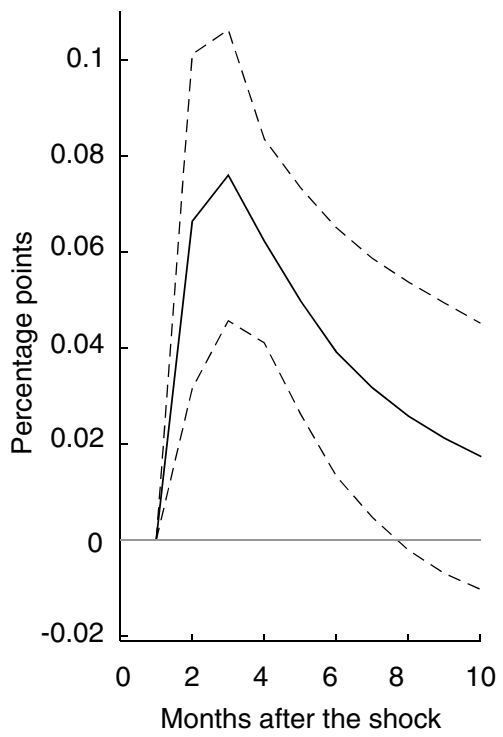

Median value of CISS

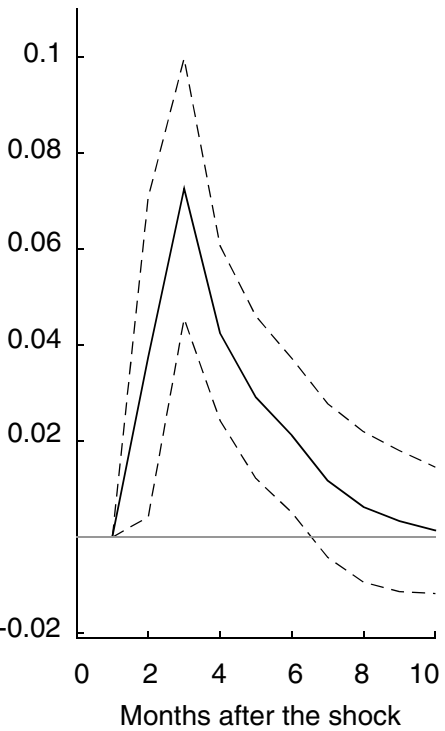

$90^{\text {th }}$ percentile of CISS

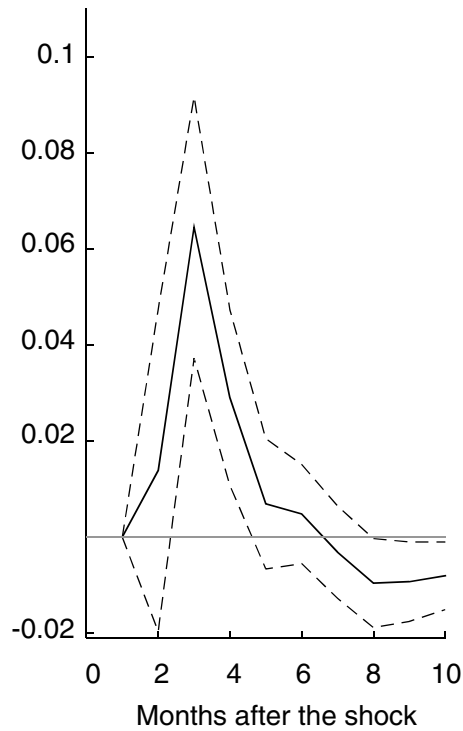

Note: These graphs are the responses of the real borrowing cost following a shock of +1 standard deviation of the EONIA rate conditional to systemic risk, measured by the composite indicator of system stress (CISS). The model is estimated over the period September 2008 to December 2014. We consider the minimum value, the median and $90^{\text {th }}$ percentile of CISS. The solid line is the estimated response while the dotted lines represent the $95 \%$ confidence interval. 
notably because of the worsening of the problems of asymmetry of information, which turn to reduce the transmission of monetary policy. From this point of view, the effects of unconventional measures would have been more limited in countries such as Greece, Spain and Portugal, comparatively to less risky countries like Germany and Austria.

\section{Impact of the health of the banking sector}

The characteristics relating to the banking sector may influence the effectiveness of monetary policy. This is what we examine first of all by considering the size of the banking sector as a conditionning variable, measured by the ratio of credit to GDP. Figure $\mathrm{V}$ shows that the bigger the size of the banking sector, the stronger the link between the EONIA and the borrowing cost. Banks play a critical role in the transmission of monetary policy. However, this transmission may be influenced by the banking sector's health.

In this regard, we examine first of all the influence of the banking sector's liquidity and capitalisation. We observe barely any difference in responses of the cost of credit to a shock to the EONIA, at a time when unconventional monetary policy measures are being implemented, whether bank liquidity is considerable or not (we just about see a slight long-lasting response when the liquidity ratio is very high; see figure C2-II of online complement C2).

However, the responses of the cost of credit are not homogeneous in terms of bank capitalisation (measured by banks' capital and reserves over GDP) (figure C2-III of online complement $\mathrm{C} 2$ ). In fact, the higher the capitalisation, the more the pass-through of the EONIA rate to the cost of credit is weakened. This result is usual: the best-capitalised banking sectors adjust less quickly and less completely the monetary policy impulses on to lending rates. Well capitalised banks have easier access to market financing; they are therefore less sensitive to monetary policy shock.

Finally, we note that the greater the non-performing loans, the more the pass-through is disrupted (figure $\mathrm{C} 2-\mathrm{IV}$, online complement $\mathrm{C} 2$ ). All other things being equal, monetary policy shocks might not have the desired effects where the ratio of non-performing loans is high (like in Greece, Italy and Ireland). The cleaning-up of balance sheets is a necessary condition so that unconventional monetary policy may achieve its objectives. Especially given that in the countries where banks have been the most affected,

Figure $\mathrm{V}$

Responses of the borrowing cost to an EONIA shock conditional to the size of the banking sector
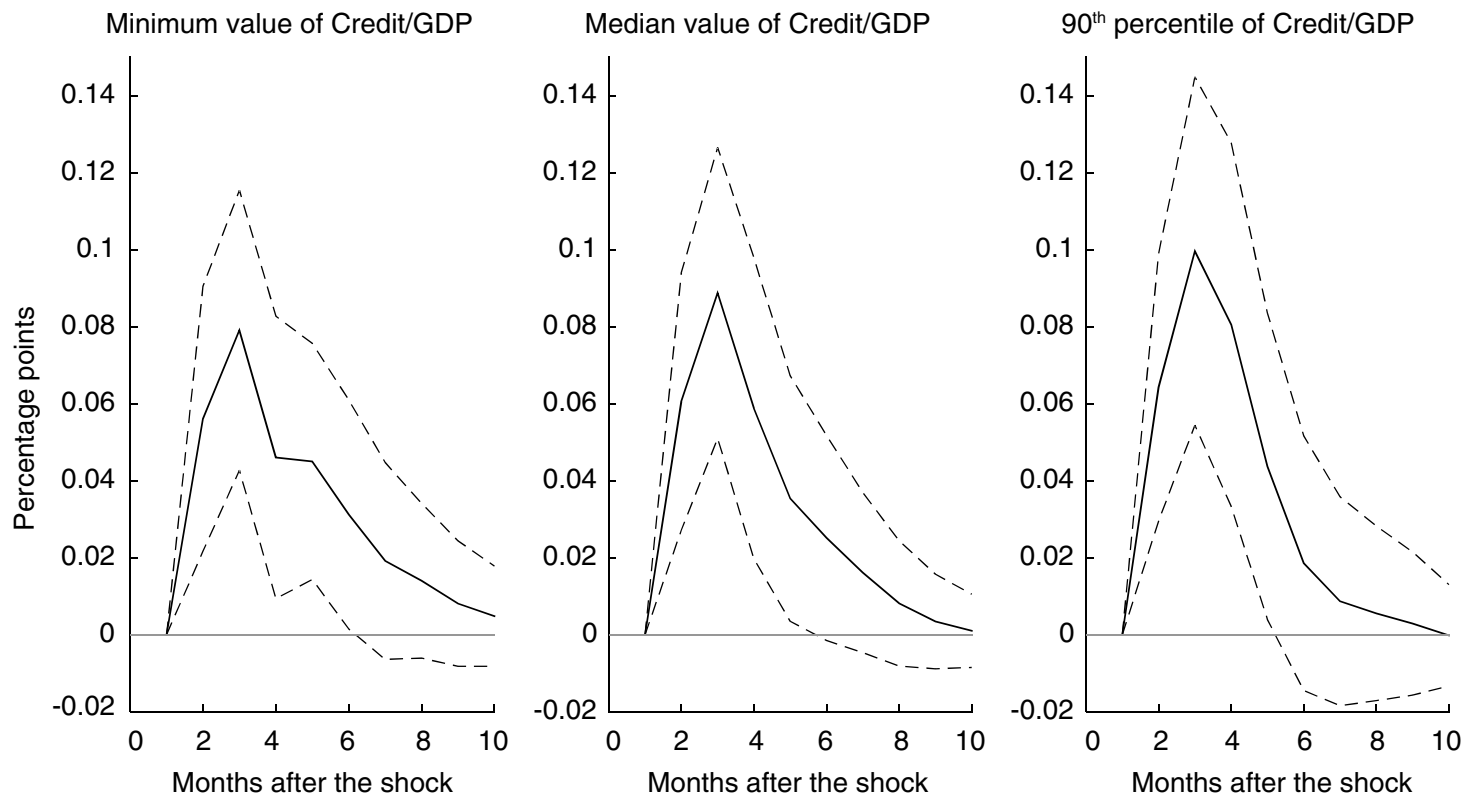

Note: These graphs are the responses of the real borrowing cost following a shock of +1 standard deviation of the EONIA rate conditional to the size of the banking sector size measured by the ratio Credit/GDP. The model is estimated over the period September 2008 to December 2014 We consider the minimum value, the median and the $90^{\text {th }}$ percentile of the ratio of credit on GDP over the estimation period. The solid line is the estimated response while the dotted lines represent the $95 \%$ confidence interval. 
non-standard measures of monetary policy have been employed to satisfy liquidity needs rather than to lower the lending rate, at least at first glance (Saborowski \& Weber, 2013).

\section{Influence of the financial structure of economies}

The literature on the determinants of the pass-through of monetary policy often highlights the negative effect of the financial architecture. ${ }^{16}$ The latter, characterised in its most usual sense by bank competition, the concentration of banks and stock market capitalisation, could also influence the indirect effects of unconventional monetary policy.

The conditional responses of the real borrowing cost appear rather homogeneous with the level of competition (measured by the Lerner index) ${ }^{17}$, as well that of concentration in the banking sector (measured by the Herfindahl-Hirschman index) (see figures $\mathrm{C} 2-\mathrm{V}$ and $\mathrm{C} 2-\mathrm{VI}$, online complement C2).

Finally, we show in figure VI the pass-through of the indirect effects of monetary policy conditional to the ratio of stock market capitalisation on GDP. This variable is of course a measure of financial development, but it does at the same time highlight the importance of markets in the overall financial system. Put in another way, it constitutes a measure of the level of market-based systems in contrast with bank-based systems (Mojon, 2001). The development of financial markets is meant to positively contribute to the transmission of monetary policy impulses, since it bolsters competition from the point of view of loanable funds. The positive effect of competition might therefore have more impact on the financial system as a whole than in the sole banking sector.

This article proposed to assess the effects of unconventional monetary policies on the cost of credit in the eurozone. With regards to the existing literature, our contribution is original in several respects: we consider all the

16. See for example Leroy \& Lucotte (2015), Sorensen \& Werner (2006) Van Leuvensteijn et al. (2013).

17. The higher the Lerner index, the weaker the competition.

Figure VI

Responses of the borrowing cost to an EONIA shock conditional to stock market capitalisation

Minimum value of stock market capitalisation Median value of stock market capitalisation $90^{\text {th }}$ percentile of stock market capitalisation
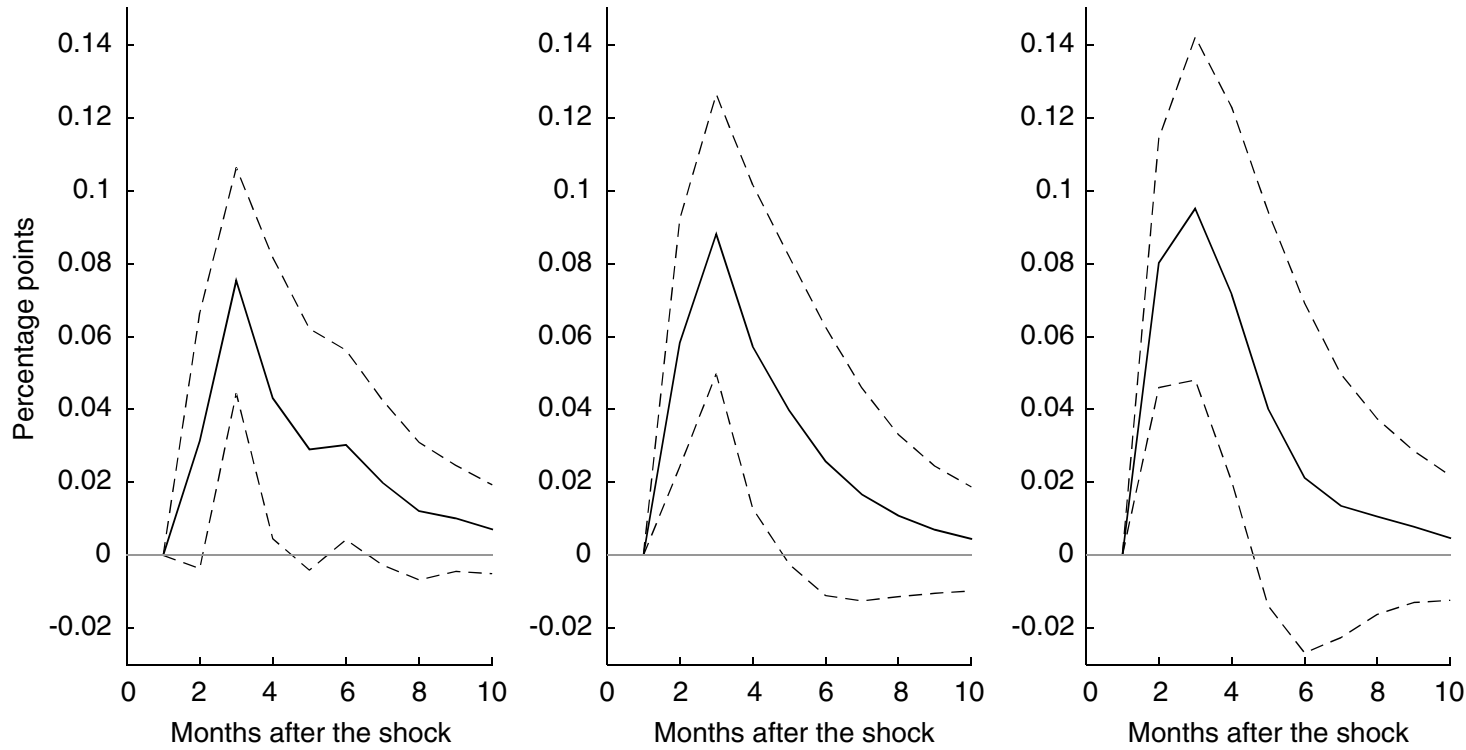

Note: These graphs are the responses of the real borrowing cost following a shock of +1 standard deviation of the EONIA rate conditional to stock market capitalisation. The model is estimated over the period September 2008 to December 2014 . We consider the minimum value, the median and $90^{\text {th }}$ percentile of stock market capitalisation. The solid line is the estimated response while the dotted lines represent the $95 \%$ confidence interval. 
unconventional measures put in place by the ECB (up until 2014), we study their impact on 11 countries in the eurozone, we distinguish their direct effects from their indirect effects, and we seek to explain the asymmetry of their impact in the member States of the eurozone.

Firstly, we describe the measures implemented by the ECB since 2008 as well as the transmission channels of UMPs. We stress that it is important to distinguish the direct effects from the indirect effects of these measures on the cost of credit. The indirect effects come down to the fact that UMPs are, also and overall, measures to accompany (low) interest rates policy. From this point of view, these measures are meant to draw the link - broken at the height of the crisis - between base interest rates and credit conditions. They should restore the functioning of the usual transmission channels of conventional monetary policy.

Our empirical analysis shows that the direct effects are very limited. More specifically, the operations of foreign currency swap, of relaxing guarantee conditions, as well as asset purchase programs (OMT, SMP and CBPP), have not had any direct impact on the cost of credit. Only the fixed-rate full allotment (FRFA) and of long-term refinancing operations (LTROs) have had significant direct effects. Also, Austria, Finland, France, the Netherlands and Italy would not have benefited from any direct effect, whatever the measure considered. The indirect effects are more compelling. Our econometric results validate the presumed complementarity between unconventional measures of monetary policy and zero rate policy. Each measure had an indirect effect on at least one country. However, some countries benefited less than others (this is the case for Ireland, for example).

This observation leads us finally to study the causes of this heterogeneity of the impact of the indirect effects of unconventional measures. Specifically, we seek to evaluate the impact of policy rates conditional to certain structural and short-term economic characteristics of the economies under study, in a time when unconventional measures of monetary policy are being implemented. We use a panel conditionally homogeneous VAR model (PCHVAR). We find that the asymmetry of the responses to a policy shock in the eurozone is explained, on the one hand, by macro-financial differences: growth rate, probability of default, public debt and systemic risk. They are explained, on the other hand, by the heterogeneity of the banking sectors, through differences in capitalisation and the size of non-performing loans. Competition and financial concentration would have had a lesser effect on the differences of transmission. So, from this point of view, and overall, the effects of unconventional policy implemented by the ECB have been greater in Germany and Austria, for example, than in Greece, Italy, Spain or Portugal.

Indeed, unconventional monetary policies have overall contributed to the reduction of the cost of credit in Europe. But high public debt, high systemic risk, weak growth, strong probability of default and a high proportion of non-performing loans have somehow reduce their impact. Therefore, these measures are not sufficient to reduce the risk of fragmentation. From this point of view, unconventional monetary policies have not necessarily been the most effective where the needs were comparatively the greatest in terms of the cost of credit. First of all, over the course of the financial crisis, we saw a bank credit rationing in certain countries. Then, with the sovereign debt crisis, the cost of bank financing increased, aggravating the difficulties in financing NFCs and consequently their default risk. All these developments increased the heterogeneity in the transmission of monetary policy.

However, these observations do not mean that the unconventional measures have been useless. As the ECB highlights, "unlimited provision of central bank liquidity to banks at a fixed rate exerted significant downward pressure on money market rates and bank lending rates. Consequently, interest rates on short-term loans declined steadily. Likewise, overall financial market volatility decreased substantially."18 But complementary measures, on the national level, such as budget support, the creation of defeasance structures, public debt restructuring and/or structural reforms, would have been (or are still) necessary for the most affected countries.

18. Arguments put forward by José Manuel González-Páramo, Member of the Board of Directors of the ECB during the conference organised by Cámara de Comercio de Málaga [Malaga Conference Room] and the University of Malaga in Malaga on 18 June 2010. 


\section{BIBLIOGRAPHY}

Abbassi, P. \& Linzert, T. (2012). The effectiveness of monetary policy in steering money market rates during the financial crisis. Journal of Macroeconomics, 34(4), 945-954.

Aït-Sahalia, Y., Andritzky, J., Jobst, A., Nowak, S. \& Tamirisa, N. (2012). Market response to policy initiatives during the global financial crisis. Journal of International Economics, 87(1), 162-177.

Altunbas, Y., Gambacorta, L. \& Marques-Ibanez, D. (2009). Securitisation and the bank lending channel. European Economic Review, 53(8), 996-1009.

Altunbas, Y., Gambacorta, L., \& MarquesIbanez, D. (2010). Bank risk and monetary policy. Journal of Financial Stability, 6(3), 121-129.

Antonin, C., Blot, C., Creel, J., Labondance, F., Touzé, V. \& Hubert, P. (2014). Comment lutter contre la fragmentation du système bancaire de la zone euro ? Revue de l'OFCE, 136(5), 171-219. doi: 10.3917/reof.136.0169

Avouyi-Dovi, S., Horny, G. \& Sevestre, P. (2017). The stability of short-term interest rates pass-through in the euro area during the financial market and sovereign debt crises. Journal of Banking \& Finance, 79, 74-94.

Beaupain, R. \& Durré, A. (2016). Excess liquidity and the money market in the euro area. Journal of Macroeconomics, 47(Part A), 33-44.

Bernanke, B., Reinhart, V. \& Sack, B. (2004). Monetary policy alternatives at the zero bound: An empirical assessment. Brookings Papers on Economic Activity, 2004(2), 1-100.

Bocola, L. (2016). The pass-through of sovereign risk. Journal of Political Economy, 124(4), 879-926.

Borio, C. \& Disyatat, P. (2010). Unconventional monetary policies: An appraisal. The Manchester School, 78, 53-89.

Bottero, M., Lenzu, S. \& Mezzanotti, F. (2015). Sovereign debt exposure and the bank lending channel: impact on credit supply and the real economy. Banca d'Italia, Working paper No. 1032.

http://www.bancaditalia.it/pubblicazioni/temi-discussione/2015/2015-1032/en_tema_1032.pdf

Carpenter, S., Demiralp, S. \& Eisenschmidt, J. (2014). The effectiveness of non-standard monetary policy in addressing liquidity risk during the financial crisis: The experiences of the Federal Reserve and the European Central Bank. Journal of Economic Dynamics and Control, 43(C), 107-129.
Cheun, S., von Köppen-Mertes, I. \& Weller, B. (2009). The collateral frameworks of the eurosystem, the federal reserve system and the bank of england and the financial market turmoil. European Central Bank, Occasional Paper Series No. 107. https://www.ecb.europa.eu/pub/pdf/scpops/ ecbocp107.pdf

Cour-Thimann, P. \& Winkler, B. (2012). The ECB's non-standard monetary policy measures: the role of institutional factors and financial structure. Oxford Review of Economic Policy, 28(4), 765-803.

Creel, J., Hubert, P. \& Viennot, M. (2016). The effect of ECB monetary policies on interest rates and volumes. Applied Economics, 48(47), 4477-4501.

Darracq Paries, M. \& De Santis, R. A. (2015). A non-standard monetary policy shock: the ECB's 3 -year LTROs and the shift in credit supply. Journal of International Money and Finance, 54, 1-34.

De Bondt, G. (2002). Retail bank interest rate pass-through: new evidence at the euro area level. European Central Bank, Working paper No. 136. https://www.ecb.europa.eu/pub/pdf/scpops/ ecbocp107.pdf

Eser, F. \& Schwaab, B. (2016). Evaluating the impact of unconventional monetary policy measures: Empirical evidence from the ECB's securities markets programme. Journal of Financial Economics, 119(1), 147-167.

Fourel, V. \& Idier, J. (2011). Risk aversion and Uncertainty in European Sovereign Bond Markets. Banque de France, Working paper No. 349. https://publications.banque-france.fr/sites/default/files/ medias/documents/working-paper_349_2011.pdf

Gambacorta, L., \& Marques-Ibanez, D. (2011). The bank lending channel: lessons from the crisis. Economic Policy, 26(66), 135-182.

Gambacorta, L., Hofmann, B. \& Peersman, G. (2014). The effectiveness of unconventional monetary policy at the zero lower bound: A cross-country analysis. Journal of Money, Credit and Banking, 46(4), 615-642.

Georgiadis, G. (2014). Towards an explanation of cross-country asymmetries in monetary transmission. Journal of Macroeconomics, 39(Part A), 66-84.

Giannone, D., Lenza, M., Pill, H. \& Reichlin, L. (2012). The ECB and the interbank market. The Economic Journal, 122(564), F467-F486. 
Gibson, H. D., Hall, S. G. \& Tavlas, G. S. (2016). The effectiveness of the ECB's asset purchase programs of 2009 to 2012. Journal of Macroeconomics, 47(Part A), 45-57.

Goodfriend, M. (2000). Overcoming the zero bound on interest rate policy. Journal of Money, Credit and Banking, 32(4), 1007-1035.

Goodhart, C. A. E. \& Ashworth, J. P. (2012). QE: a successful start may be running into diminishing returns. Oxford Review of Economic Policy, 28(4), 640-670.

Hesse, H. \& Frank, N. (2009). The effectiveness of central bank interventions during the first phase of the subprime crisis. International Monetary Fund, Working Paper No. 09/206.

https://ssrn.com/abstract $=1486524$

Horny, G., Manganelli, S. \& Mojon, B. (2016). Measuring financial fragmentation in the euro area corporate bond market. Banque de France, Document de travail No. 582.

https://publications.banque-france.fr/sites/default/files/ medias/documents/working-paper_582_2016.pdf

Lenza, M., Pill, H. \& Reichlin, L. (2010). Monetary policy in exceptional times. Economic Policy, 25(62), 295-339.

Leroy, A. \& Lucotte, Y. (2015). Heterogeneous monetary transmission process in the eurozone: Does banking competition matter? International Economics, 141, 115-134.

Leroy, A. \& Lucotte, Y. (2016). Structural and cyclical determinants of bank interest-rate pass-through in the eurozone. Comparative Economic Studies, 58(2), 196-225.

McCallum, B. T. (2000). Theoretical analysis regarding a zero lower bound on nominal interest rates. Journal of Money, Credit and Banking, 32(4), 870-904.

McGough, B., Rudebusch, G. D. \& Williams, J. C. (2005). Using a long-term interest rate as the monetary policy instrument. Journal of Monetary Economics, 52(5), 855-879.

Mojon, B. (2001). Structures financières et canal des taux d'intérêt de la poltique monétaire dans la zone euro. Economie \& Prévision, 147(1), 89-115.

http://www.persee.fr/doc/ecop_0249-4744_ 2001_num_147_1_6216

Peersman, G. (2011). Macroeconomic effects of unconventional monetary policy in the euro area. Working Paper Series 1397, European Central Bank. https://www.ecb.europa.eu/pub/pdf/scpwps/ecbwp 1397.pdf?99ef78cb1aa613f60d8716d0db59b585

Popov, A. A. \& Van Horen, N. (2013). The impact of sovereign debt exposure on bank lending: Evidence from the european debt crisis. De Nederlandsche Bank, Working paper No. 382.

https://www.cass.city.ac.uk/_data/assets/pdf_ file/0015/171105/19.-Popov-v2.pdf

Praet, P. (2016). The ECB and its role as lender of last resort during the crisis. Discours lors de la Conférence « Le prêteur en dernier ressort - une perspective internationale », Comité des marchés financiers. Washington DC, 10 février 2016.

htpps://www.ecb.europa.eu/press/key/date/2016/ html/sp1602010.en.html

Saborowski, C. \& Weber, M. S. (2013). Assessing the determinants of interest rate transmission through conditional impulse response functions. International Monetary Fund, Working Paper, No. 13/23. http://www.imf.org/ /media/Websites/IMF/importedfull-text-df/external/pubs/ft/wp/2013/_wp1323.ashx

Sorensen, C. K. \& Werner, T. (2006). Bank interest rate pass-through in the euro area: a cross country comparison. European Central Bank, Working Paper Series No. 580.

https://www.ecb.europa.eu/pub/pdf/scpwps/ecbwp 580.pdf?63c54c4f654bbce1b9cdfbe2bea9a100

Szczerbowicz, U. (2015). The ECB unconventional monetary policies: have they lowered market borrowing costs for banks and governments? International Journal of Central Banking, 11(4), 91-127.

Trichet, J.-C. (2009). The ECB's enhanced credit support. Keynote address at the university of Munich, Munich Seminar.

https://www.ecb.europa.eu/press/key/date/2009/ html/sp090713.en.html

Trichet, J.-C. (2010). State of the union: The financial crisis and the ECB's response between 2007 and 2009. Journal of Common Market Studies, 48, 7-19.

Valverde, S. C. \& Fernández, F. R. (2007). The determinants of bank margins in European banking. Journal of Banking \& Finance, 31(7), 2043-2063.

Van Leuvensteijn, M., Sorensen, C. K., Bikker, J. A. \& Van Rixtel, A. A. (2013). Impact of bank competition on the interest rate pass-through in the euro area. Applied Economics, 45(11), 1359-1380.

Wu, J. C., \& Xia, F. D. (2016). Measuring the macroeconomic impact of monetary policy at the zero lower bound. Journal of Money, Credit and Banking, 48(2-3), 253-291. 